\title{
Perbandingan Metode Pengujian Teori TAM Pada Penerimaan Teknologi E-Money di Pontianak
}

\author{
Irawan Wingdes*, Sandy Kosasi, I Dewa Ayu Eka Yuliani \\ Program Studi Sistem Informasi, STMIK Pontianak \\ Naskah Diterima : 17 Desember 2020; Diterima Publikasi : 8 April 2021
}

DOI: 10.21456/voll1iss1pp26-33

\begin{abstract}
As a researcher, one could analyze Technology Acceptance Model (TAM) by utilizing several methods. Such methods are summated scales regression, factor analysis score regression, covariance-based SEM, and PLS-based SEM. However, there exists less effort to compare the difference in estimates of these methods in a single dataset. The differing estimates could therefore lead to type I statistical errors. This research purpose was to compare these methods objectively with a single dataset. The dataset tested was derived from e-money research in Pontianak, with 280 data collected at refueling stations during May, June, July 2020. This research contributes to proofing how method choices will produce a differing interpretation even though tested on the same dataset. Summated scale regression and PLS-based SEM produced similar estimation results but differed from factor analysis score regression and covariance-based SEM. Further testing implies that the different estimates are due to the elimination of indicators, which is method-specific. Therefore, method justification, completeness of research report, and research context are crucial for accounting limitation of the method chosen. PLS-based SEM was a suitable method for data utilized with $50,3 \%$ variability in usefulness, $58 \%$ variability in intention to use is accounted for from the research model.
\end{abstract}

Keywords : TAM; Regression; Factor Analysis; SEM.

\begin{abstract}
Abstrak
Technology Acceptance Model (TAM) dapat diuji dengan rangkaian variasi metode pengujian. Metode tersebut yaitu regresi dengan penjumlahan skor, regresi dengan skor analisis faktor, SEM berbasis kovarian, dan SEM berbasis PLS. Namun, perbedaan variasi metode tersebut tidak umum dibandingkan walaupun estimasi berpotensi berbeda sehingga meningkatkan kemungkinan kesalahan statistik tipe I. Tujuan dari penelitian ini adalah membandingkan serangkaian metode tersebut secara objektif pada data yang sama. Data yang diuji merupakan bagian dari data survei tentang penerimaan teknologi e-money berjumlah 280 responden yang dikumpulkan pada stasiun pengisian yang dipilih secara acak pada periode bulan Mei, Juni, Juli 2020. Penelitian berkontribusi pada membuktikan bahwa perbedaan metode memberikan kesimpulan yang berbeda walaupun diujikan pada data yang sama. Hasil perbandingan menunjukkan terdapat perbedaan estimasi yang terbagi dua dimana regresi penjumlahan skor menyerupai SEM berbasis PLS, dan regresi skor analisis faktor menyerupai SEM berbasis kovarian. Pengujian lanjutan menunjukkan bahwa salah satu penyebab inkonsistensi terdapat pada proses eliminasi indikator, dimana akan tergantung pada metode yang dipilih sehingga berimplikasi pada perlunya justifikasi pemilihan metode dan pelaporan yang lengkap sesuai konteks penelitian. SEM berbasis PLS menjadi metode yang sesuai konteks kasus data dengan kemampuan menjelaskan perubahan variabel kegunaan $\left(\mathrm{R}^{2}\right)$ sebesar 50,3\%, dan intensi menggunakan sebesar $58 \%$.
\end{abstract}

Kata kunci : TAM; Regresi; Analisis Faktor; SEM

\section{Pendahuluan}

Technology Acceptance Model (TAM) merupakan sebuah teori yang dikembangkan untuk menjelaskan fenomena penerimaan teknologi maupun inovasi baru dalam ranah ilmu sistem informasi (Davis et al., 1983). Teori ini telah dikembangkan oleh Davis sejak tahun 1989 yang mengambil dasar teori Theory of Reasoned Action (Dwivedi et al., 2019).

Sejak 1989 hingga saat ini, teori ini telah berulang kali diuji dan hasil yang didapatkan konsisten untuk

*) Penulis korespondensi: irawan.wingdes@gmail.com menjelaskan penerimaan teknologi. Pada saat teori TAM dikembangkan oleh Davis, teknik pengujian yang diutiliasi adalah analisis faktor yang kemudian dilanjutkan dengan regresi menggunakan skor analisis faktor tersebut. Sejak publikasi teori tersebut, metode pengujian model (hubungan antar konstruk) dalam kerangka teori TAM menggunakan beberapa metode, yaitu: SEM berbasis kovarian / CBSEM (LISREL / AMOS), SEM berbasis varians / SEMPLS (PLS / SmartPLS / WarpPLS), analisis konjoin, maupun tetap menggunakan skor hasil analisis faktor 
yang kemudian dilanjutkan dengan regresi. Selain ketiga metode tersebut, terdapat satu alternatif pengujian lain yaitu regresi dengan nilai composite atau penjumlahan skor (Shevlin et al., 1997).

Merujuk sejumlah penelitian sebelumnya di Indonesia, perbedaan metode pengujian tersebut terbukti melalui sebuah pencarian sederhana pada portal jurnal Indonesia yaitu portal GARUDA (RISTEK DIKTI, 2020). Berdasarkan 15 hasil pencarian pertama, 3 metode yang digunakan oleh peneliti terdahulu dalam menguji teori TAM adalah sebanyak $13 \%$ menggunakan CBSEM, $47 \%$ SEMPLS, $20 \%$ regresi penjumlahan skor, dan $20 \%$ tidak teridentifikasi. Pencarian kembali dilakukan pada salah satu portal penelitian internasional, yaitu Elsevier dengan kata kunci yang sama (Elsevier, 2020). Hasil yang didapatkan adalah $13,3 \%$ meta analitis, $6,67 \%$ regresi, $40 \%$ CBSEM, dan $40 \%$ SEMPLS dari 15 hasil pencarian pertama.

Perbedaan metode pengujian model tersebut cenderung membingungkan karena dapat menghasilkan estimasi dengan hasil yang berbeda. Perbedaan estimasi tersebut kemudian akan meningkatkan potensi kesalahan tipe I dimana menolak hipotesis null pada saat hipotesis null benar pada taraf signifikansi tertentu (Tabachnick dan Fidell, 2013).

Berdasarkan pengalaman selama ini, dimana penelitian berbasis design research (Blessing dan Chakrabarti, 2009), juga seringkali terjadi bahwa pengujian penerimaan pengguna belum merujuk pada penentuan kriteria pengujian yang ideal. Sejumlah temuan diantaranya terkait dengan jumlah sampel yang kecil, hubungan antar konstruk dalam model penelitian belum teruji, sampai keperluan pengembangan model pengujian spesifik yang hanya ditujukan pada kebutuhan penelitian cross sectional saja. Merujuk pada kondisi-kondisi tersebut, maka dengan menggunakan metode pengujian teori yang tepat akan mendukung artefak yang dikembangkan dari sebuah penelitian (Cash, 2020). Oleh karena itu, dibutuhkan penelitian untuk membandingkan berbagai metode tersebut secara objektif menggunakan sumber data yang sama.

Sepengetahuan peneliti, belum ada penelitian serupa sebelumnya yang menguji perbedaan metode tersebut sekaligus pada data yang serupa. Tujuan dari penelitian ini adalah membandingkan beberapa metode pengujian yang teridentifikasi sebelumnya, khususnya pada penerimaan teknologi dengan teori TAM. Pertanyaan yang berusaha dijawab adalah bagaimana perbedaan estimasi dari beberapa metode tersebut berpotensi menimbulkan perbedaan estimasi dan kemudian memengaruhi kesimpulan penelitian.

Perbandingan pengujian dari sejumlah metode tersebut dilakukan berdasarkan menggunakan data hasil survei penerimaan teknologi e-money di Pontianak dengan teori TAM dan merupakan bagian dari penelitian yang dilaksanakan dengan pendanaan hibah dari DIKTI tahun 2020. Kota Pontianak sudah menerapkan teknologi e-money sejak tahun 2019, tetapi untuk implementasinya berulang kali mengalami kegagalan (Ishak, 2019; Syahroni, 2018) sehingga data survei tersebut menjadi topik yang selaras untuk menjelaskan penerimaan teknologi dengan teori TAM. Perbandingan metode pengujian menggunakan regresi penjumlahan skor dan regresi skor analisis faktor dengan bantuan software SPSS 25, menggunakan CBSEM dengan AMOS 22 dan menggunakan SEMPLS dengan SmartPLS 3.2.8. Setelah perbandingan dikaji, dipilih satu hasil pengujian yang kemudian digunakan untuk menjelaskan fenomena penerimaan teknologi $e$ money di Pontianak.

\section{Kerangka Teori}

Merujuk penelitian sosial, mengukur sebuah fenomena dilakukan dengan menggunakan konsep berdimensi tunggal maupun konsep multidimensi (variabel laten). Teori TAM, mengukur fenomena penerimaan teknologi melalui beberapa dimensi yaitu penggunaan sebuah teknologi didahului oleh niat menggunakan, dimana niat tersebut didahului juga oleh persepsi kegunaan, persepsi kemudahan, dan dimensi-dimensi lainnya yang disebut ekstensi.

Selanjutnya objek pembahasan merujuk pada hasil implementasi penerimaan teknologi e-money di Pontianak, konseptualisasi penggunaan e-money dilakukan dengan menggunakan konstruk atau dimensi yang sudah diujikan studi-studi TAM sebelumnya (Mortimer et al., 2015; Baptista dan Oliveira, 2015; Lok, 2015; Venkatesh dan Davis, 2000). Gambar konseptualisasi penggunaan e-money pada penelitian ini dapat dilihat pada Gambar 1, hipotesis yang digunakan sebagai berikut:

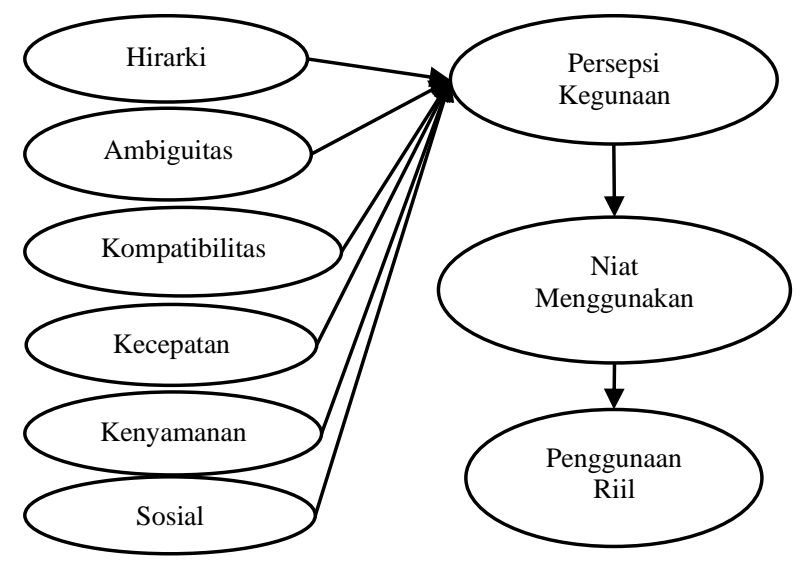

Gambar 1. Model konseptual pengujian

$\mathrm{H}_{1}$ : Kegunaan memengaruhi niat Menggunakan secara positif

$\mathrm{H}_{2}$ : Niat Menggunakan memengaruhi Penggunaan riil secara positif 
$\mathrm{H}_{3}$ : Hirarki memengaruhi Persepsi kegunaan dengan negatif

$\mathrm{H}_{4}$ : Ambiguitas memengaruhi persepsi kegunaan dengan negatif

$\mathrm{H}_{5}$ : Kompatibilitas memengaruhi persepsi kegunaan dengan positif

$\mathrm{H}_{6}$ : Kecepatan memengaruhi persepsi kegunaan dengan positif

$\mathrm{H}_{7}$ : Kenyamanan memengaruhi persepsi kegunaan dengan positif

$\mathrm{H}_{8}$ : Tekanan sosial memengaruhi persepsi kegunaan dengan positif

Regresi linear dengan metode ordinary least square merupakan upaya mencari hubungan antara dua variabel atau lebih secara garis lurus (Tabachnick dan Fidell, 2013). Pada pengujian variabel laten, dimana tidak dapat diobservasi langsung melainkan diwakili oleh beberapa alat ukur/ indikator, maka pengujian dilakukan dengan menambahkan skor dari setiap indikator (Shevlin et al., 1997). Analisis faktor (Matsunaga, 2011) pada dasarnya menyederhanakan hubungan indikator menjadi sebuah variabel laten dengan teknik proyeksi matrix matematis/common factor (Gorsuch, 1983). Pada analisis faktor, indikator yang diuji dapat berpadu secara bebas membentuk variabel laten/ exploratory.

Perkembangan dari pengujian variabel laten dilanjutkan dengan kombinasi antara analisis path dengan analisis faktor atau structural equation modeling/ SEM (Bollen, 1989). Pengujian hubungan SEM mengikutsertakan batasan dan bersifat confirmatory/ indikator tidak berpadu secara bebas (Tóth-Király et al., 2017). SEM terbagi 2, yaitu SEM yang dikembangkan dari kovarian/ common factor/ CBSEM dan SEM berbasis component/ SEMPLS (Velicer dan Jackson, 1990).

\section{Metode}

Pengujian model dilakukan dengan 4 metode ditambah dengan hasil simulasi Monte Carlo.

Sampel berasal dari 280 pengguna kendaraan bermotor dan pengumpulan data tersebut dilakukan pada periode Mei-Juni-Juli 2020 dengan judgment sampling pada stasiun pengisian bahan bakar Pontianak. Kategori responden adalah pernah menggunakan e-money di SPBU minimal satu kali atau mengetahui tentang e-money dan paham cara menggunakan. Data dikumpulkan dengan metode survei dengan bantuan angket fisik/ kertas. Survei dilaksanakan setiap tiga hari per minggu pada periode survei di jam dan lokasi SPBU acak.

Indikator (pertanyaan kuesioner) diadaptasi dari studi terdahulu, yaitu dari (Mortimer et al., 2015; Baptista dan Oliveira, 2015; Lok, 2015; Venkatesh dan Davis, 2000). Penerjemahan dan penyesuaian dilakukan dengan teknik focused group discussion yang beranggotakan dosen bahasa inggris, mahasiswa, dan anggota masyarakat. Selanjutnya, dilakukan pretest dengan diuji ke sampel kecil (30 responden) sebelum disebarkan secara fisik pada responden sebenarnya. Skala pengukuran menggunakan Likert (1 sangat tidak setuju, 5 netral dan 9 sangat setuju).

Pengujian dimensi dalam konsep yang hubungannya tertera dalam model penelitian dilakukan dengan empat metode, yaitu:

1. Pengujian regresi dengan penjumlahan skor indikator $\quad(\mathrm{PD} 1+\mathrm{PD} 2+\mathrm{PD} 3+\mathrm{PD} 4=\mathrm{PD}, \quad$ dan seterusnya).

2. Analisis faktor yang hasilnya disimpan dan pengujian hubungan dilakukan dengan regresi menggunakan skor tersebut.

3. Menggunakan SEM berbasis PLS

4. Menggunakan SEM berbasis kovarian (CBSEM).

Tahapan pengujian tersebut merujuk pada Gambar 2.

\begin{tabular}{|c|c|c|}
\hline Tahap 1 & Tahap 2 & Tahap 3 \\
\hline $\begin{array}{c}\text { Regresi } \\
\text { Penjumlahan } \\
\text { Skor } \\
\text { Analisis Faktor } \\
+ \text { Regresi } \\
\text { SEMPLS } \\
\text { CBSEM }\end{array}$ & $\begin{array}{c}\text { Eliminasi } \\
\text { indikator iteratif. } \\
\text { (eliminasi } \\
\text { indikator dengan } \\
\text { kriteria salah satu } \\
\text { metode pada } \\
\text { semua teknik dan } \\
\text { sebaliknya) }\end{array}$ & $\begin{array}{c}\text { Menciptakan } \\
\text { data dengan } \\
\text { simulasi } \\
\text { Monte Carlo, } \\
\text { diujikan pada } \\
4 \text { metode, } \\
\text { dibandingkan } \\
\text { dengan hasil } \\
\text { tahap } 1 .\end{array}$ \\
\hline
\end{tabular}

Gambar 2. Tahapan pengujian

Simulasi Monte Carlo dilakukan dengan menggunakan data sampel yang direplikasi ulang pada kondisi lebih ideal dengan data berdistribusi normal. Informasi matriks korelasi antar variabel laten maupun mean/stdev indikator berasal dari sampel. Validitas konstruk diperbaiki dengan kriteria ideal loading factor $>0.8$ dan berjumlah 1000 data (Carsey dan Harden, 2014).

\section{Hasil dan Pembahasan}

\subsection{Regresi}

Asumsi klasik regresi terpenuhi dimana normalitas data tercapai dengan skewness dan kurtosis <1 (Hair, 2010). Hasil regresi tidak menunjukkan adanya outlier dan tidak ada multikolinearitas (VIF <5). Khusus pada variabel penggunaan riil, data menyebar kiri (skewness positif $>1$ ) tetapi pada proses pengujian diabaikan karena hasil regresi sebelum dan setelah dilakukan transformasi log linear (supaya nilai skewness <1) tetap sama.

Hasil pengujian asumsi juga tercapai pada pengujian hubungan USE ke INT, dan INT ke Usage. Nilai korelasi dan signifikansi dapat dilihat pada Tabel 1 pada kolom regresi sampel. 
$\underline{\text { Tabel 1. Perbandingan korelasi/ signifikansi pengujian (Sampel dan Monte Carlo) }}$

\begin{tabular}{|c|c|c|c|c|c|c|c|c|}
\hline & \multicolumn{2}{|c|}{ Regresi } & \multicolumn{2}{|c|}{ Analisis Faktor } & \multicolumn{2}{|c|}{ SEMPLS } & \multicolumn{2}{|c|}{ CBSEM } \\
\hline & Sampel & MC & Sampel & $\mathrm{MC}$ & Sampel & $\mathrm{MC}$ & Sampel & $\mathrm{MC}$ \\
\hline PD-USE & $0.01 / \mathrm{TS}$ & $0.06 / * *$ & $0.08 / *$ & $0.01 / \mathrm{TS}$ & $0.05 / \mathrm{TS}$ & $0.06 / *$ & $0.04 / \mathrm{TS}$ & $0.07 / *$ \\
\hline UA-USE & $0.15 / * *$ & $0.11 / * *$ & $0.14 / * *$ & $0.07 / *$ & $0.17 / * *$ & $0.11 / * *$ & $0.12 / * *$ & $0.12 / * *$ \\
\hline TS-USE & $0.52 / * *$ & $0.54 / * *$ & $0.52 / * *$ & $0.33 / * *$ & $0.53 / * *$ & $0.53 / * *$ & $0.66 / * *$ & $0.54 / * *$ \\
\hline SOS-USE & $0.15 / * *$ & $0.24 / * *$ & $0.26 / * *$ & $0.13 / * *$ & $0.19 / * *$ & $0.23 / * *$ & $0.25 / * *$ & $0.24 / * *$ \\
\hline CP-USE & $0.17 / * *$ & $0.23 / * *$ & $0.25 / * *$ & $0.15 / * *$ & $0.15 / * *$ & $0.24 / * *$ & $0.19 / * *$ & $0.21 / * *$ \\
\hline COM-USE & $0.05 / \mathrm{TS}$ & $0.18 / * *$ & $0.20 / * *$ & $0.15 / * *$ & $0.08 / \mathrm{TS}$ & $0.18 / * *$ & $0.12 / * *$ & $0.19 / * *$ \\
\hline USE-INT & $0.69 / * *$ & $0.79 / * *$ & - & - & $0.76 / * *$ & $0.77 / * *$ & $0.96 / * *$ & $0.85 / * *$ \\
\hline INT-Usage & $0.23 / * *$ & $0.14 / * *$ & - & - & $0.23 / * *$ & $0.13 / * *$ & $0.25 / * *$ & $0.14 / * *$ \\
\hline
\end{tabular}

Tabel 2. Eliminasi indikator SEM dan pengaruh terhadap hubungan variabel (tahap 2)

\begin{tabular}{|c|c|c|c|c|c|c|c|c|c|c|c|c|}
\hline \multicolumn{6}{|c|}{ Loading Factor (SEMPLS) } & \multicolumn{5}{|c|}{ Loading Factor (CBSEM) } & \multirow{2}{*}{$\mathrm{X} 1$} & \multirow{2}{*}{$\mathrm{X} 2$} \\
\hline & $\mathrm{I}$ & II & III & IV & Final & $\mathrm{I}$ & II & III & IV & Final & & \\
\hline PD1 & 0.86 & 0.89 & 0.89 & 0.89 & 0.89 & 0.85 & & 0.86 & 0.85 & 0.86 & 0.89 & 0.86 \\
\hline PD2 & 0.89 & 0.92 & 0.92 & 0.92 & 0.92 & 0.86 & & 0.86 & 0.86 & 0.86 & 0.92 & 0.86 \\
\hline PD3 & -0.36 & $\mathrm{x}$ & $\mathrm{x}$ & $\mathrm{x}$ & $\mathrm{x}$ & -0.13 & $\mathrm{x}$ & $\mathrm{x}$ & $\mathrm{x}$ & $\mathrm{x}$ & $\mathrm{x}$ & $\mathrm{x}$ \\
\hline PD4 & 0.84 & 0.87 & 0.87 & 0.87 & 0.87 & 0.79 & $\mathrm{x}$ & 0.79 & 0.79 & 0.79 & 0.87 & 0.79 \\
\hline UA1 & 0.87 & 0.93 & 0.88 & 0.88 & 0.88 & 0.63 & $\mathrm{x}$ & $\mathrm{x}$ & 0.63 & $\mathrm{x}$ & $\mathrm{x}$ & 0.66 \\
\hline UA2 & 0.81 & 0.79 & 0.81 & 0.81 & 0.81 & 0.75 & $\mathrm{x}$ & 0.82 & 0.75 & 0.71 & 0.91 & 0.78 \\
\hline UA3 & 0.77 & $\mathrm{x}$ & 0.77 & 0.77 & 0.77 & 0.79 & $\mathrm{x}$ & 0.72 & 0.79 & 0.84 & 0.87 & 0.73 \\
\hline UA4 & 0.55 & $\mathrm{x}$ & $\mathrm{x}$ & $\mathrm{x}$ & $\mathrm{x}$ & 0.67 & $\mathrm{x}$ & $\mathrm{x}$ & 0.67 & 0.68 & 0.55 & $\mathrm{x}$ \\
\hline TS1 & 0.79 & $\mathrm{x}$ & 0.79 & 0.79 & 0.79 & 0.72 & $\mathrm{x}$ & 0.74 & 0.72 & 0.74 & 0.83 & 0.72 \\
\hline TS2 & 0.82 & 1.00 & 0.82 & 0.82 & 0.82 & 0.75 & $\mathrm{x}$ & 0.77 & 0.75 & 0.77 & 0.85 & 0.75 \\
\hline TS3 & 0.79 & $\mathrm{x}$ & 0.79 & 0.79 & 0.79 & 0.72 & $\mathrm{x}$ & 0.70 & 0.72 & 0.70 & 0.81 & 0.72 \\
\hline TS4 & 0.75 & $\mathrm{x}$ & 0.75 & 0.75 & 0.75 & 0.64 & $\mathrm{x}$ & $\mathrm{x}$ & 0.64 & $\mathrm{x}$ & $\mathrm{x}$ & 0.64 \\
\hline USE1 & 0.85 & 0.86 & 0.86 & 0.86 & 0.86 & 0.80 & $\mathrm{x}$ & 0.79 & 0.79 & 0.79 & 0.86 & 0.79 \\
\hline USE2 & 0.83 & 0.84 & 0.84 & 0.84 & 0.84 & 0.74 & $\mathrm{x}$ & 0.74 & 0.74 & 0.74 & 0.84 & 0.74 \\
\hline USE3 & 0.83 & 0.84 & 0.84 & 0.84 & 0.84 & 0.75 & $\mathrm{x}$ & 0.74 & 0.74 & 0.74 & 0.84 & 0.74 \\
\hline USE4 & 0.44 & $\mathrm{x}$ & $\mathrm{x}$ & $\mathrm{x}$ & $\mathrm{x}$ & 0.32 & $\mathrm{x}$ & $\mathrm{x}$ & $\mathrm{x}$ & $\mathrm{x}$ & $\mathrm{x}$ & $\mathrm{x}$ \\
\hline $\mathrm{CP} 1$ & 0.83 & 0.88 & 0.83 & 0.83 & 0.83 & 0.75 & $\mathrm{x}$ & 0.72 & 0.75 & 0.71 & 0.88 & 0.76 \\
\hline $\mathrm{CP} 2$ & 0.78 & $\mathrm{x}$ & 0.78 & 0.78 & 0.78 & 0.63 & $\mathrm{x}$ & $\mathrm{x}$ & 0.63 & $\mathrm{x}$ & $\mathrm{x}$ & 0.63 \\
\hline CP3 & 0.85 & 0.90 & 0.85 & 0.85 & 0.85 & 0.76 & $\mathrm{x}$ & 0.81 & 0.76 & 0.81 & 0.90 & 0.76 \\
\hline SOS1 & 0.89 & 0.89 & 0.89 & 0.89 & 0.89 & 0.80 & & 0.80 & 0.80 & 0.80 & 0.89 & 0.80 \\
\hline SOS2 & 0.88 & 0.88 & 0.88 & 0.88 & 0.88 & 0.83 & & 0.83 & 0.83 & 0.83 & 0.88 & 0.83 \\
\hline SOS3 & 0.85 & 0.86 & 0.86 & 0.86 & 0.86 & 0.78 & $\mathrm{x}$ & 0.77 & 0.78 & 0.78 & 0.86 & 0.78 \\
\hline COM1 & 0.40 & $\mathrm{x}$ & $\mathrm{x}$ & $\mathrm{x}$ & 0.92 & 0.92 & & 0.91 & 0.92 & 0.91 & 0.54 & 2.37 \\
\hline COM2 & 0.95 & 1.00 & 1.00 & 1.00 & $\mathrm{x}$ & 0.74 & $\mathrm{x}$ & 0.74 & 0.74 & 0.74 & -0.14 & $\mathrm{x}$ \\
\hline COM3 & 0.38 & $\mathrm{x}$ & $\mathrm{x}$ & $\mathrm{x}$ & 0.89 & 0.71 & $\mathrm{x}$ & 0.71 & 0.71 & 0.71 & 0.65 & 0.27 \\
\hline INT1 & 0.86 & 0.86 & 0.86 & 0.86 & 0.86 & 0.81 & & 0.82 & 0.81 & 0.81 & 0.86 & 0.81 \\
\hline INT2 & 0.84 & 0.84 & 0.84 & 0.84 & 0.84 & 0.74 & $\mathrm{x}$ & 0.73 & 0.74 & 0.74 & 0.84 & 0.74 \\
\hline \multirow[t]{2}{*}{ INT3 } & 0.81 & 0.81 & 0.81 & 0.81 & 0.81 & 0.69 & $\mathrm{x}$ & $\mathrm{x}$ & 0.69 & 0.69 & 0.81 & 0.69 \\
\hline & \multicolumn{12}{|c|}{ Korelasi / Signifikansi } \\
\hline PD- & 0.06 & 0.12 & 0.05 & 0.05 & 0.05 & 0.03 & TA & 0.06 & 0.03 & 0.06 & 0.09 & 0.02 \\
\hline USE & $/ \mathrm{TS}$ & /* & $/ \mathrm{TS}$ & /TS & $/ \mathrm{TS}$ & $/ \mathrm{TS}$ & IA & $/ \mathrm{TS}$ & $/ \mathrm{TS}$ & $/ \mathrm{TS}$ & /TS & $/ \mathrm{TS}$ \\
\hline UA- & 0.18 & 0.17 & 0.18 & 0.18 & 0.17 & 0.18 & TA & 0.17 & 0.17 & 0.12 & 0.11 & 0.20 \\
\hline USE & $/ * *$ & $/ * *$ & $/ * *$ & l** & /** & $/ * *$ & IA & $/ * *$ & $/ * *$ & /* & /TS & /** \\
\hline TS- & 0.53 & 0.41 & 0.54 & 0.54 & 0.53 & 0.63 & TA & 0.59 & 0.63 & 0.60 & 0.49 & 0.61 \\
\hline USE & $/ * *$ & l** & l** & l** & $/ * *$ & $/ * *$ & TA & $/ * *$ & $/ * *$ & /** & $/ * *$ & /** \\
\hline SOS- & 0.19 & 0.24 & 0.20 & 0.20 & 0.19 & 0.24 & TA & 0.26 & 0.24 & 0.26 & 0.21 & 0.24 \\
\hline USE & /** & $/ * *$ & $/ * *$ & /** & /** & l** & 1A & /** & /** & $/ * *$ & $/ * *$ & /** \\
\hline $\mathrm{CP}-$ & 0.17 & 0.20 & 0.16 & 0.16 & 0.15 & 0.20 & & 0.20 & 0.20 & 0.21 & 0.16 & 0.19 \\
\hline USE & /** & $/ * *$ & /** & l** & /** & $/ * *$ & IA & /** & $/ * *$ & /** & $/ * *$ & $/ * *$ \\
\hline COM- & 0.07 & 0.10 & 0.09 & 0.09 & 0.08 & 0.15 & & 0.11 & 0.16 & 0.16 & 0.02 & 0.04 \\
\hline USE & /TS & $/ \mathrm{TS}$ & $/ \mathrm{TS}$ & /TS & /TS & l** & TA & /** & l** & l** & $/ \mathrm{TS}$ & /TS \\
\hline USE- & 0.76 & 0.76 & 0.76 & 0.76 & 0.76 & 0.96 & & 0.96 & 0.96 & 0.96 & 0.76 & 0.96 \\
\hline INT & $/ * *$ & /** & /** & l** & l** & $/ * *$ & TA & /** & $/ * *$ & /** & $/ * *$ & l** \\
\hline INT- & 0.23 & 0.23 & 0.23 & 0.23 & 0.23 & 0.25 & & 0.24 & 0.25 & 0.25 & 0.23 & 0.25 \\
\hline Usage & /** & /** & /** & /** & /** & /** & TA & /** & $/ * *$ & /** & /** & /** \\
\hline
\end{tabular}

Tabel 2 dibagi 3 bagian. Kiri SEMPLS, kanan CBSEM, bawah korelasi/signifikansi (* 0.05, ** 0.01, TS tidak signifikan). Kolom I hasil pengujian tanpa eliminasi indikator, kolom II eliminasi loading factor $<0.8$. Kolom III eliminasi loading factor <0.7, kolom IV $<0.6, \mathrm{x}$ merupakan indikator yang dieliminasi. Kolom final merupakan kolom dengan indikator yang digunakan pada pengujian akhir. Kolom X1 merupakan eliminasi pada SEMPLS berdasar kriteria CBSEM, dan kolom X2 merupakan eliminasi pada CBSEM berdasar kriteria SEMPLS. 
Dari Tabel 1 terlihat hanya hubungan PD-USE, dan COM-USE yang tidak signifikan. Sedangkan hubungan lainnya signifikan dengan taraf signifikansi 0,05 maupun 0,01 .

\subsection{Analisis Faktor}

Analisis faktor memenuhi persyaratan dengan nilai KMO 0,829 dan sampel lebih dari 150. Analisis faktor dilakukan dengan teknik Principal Axis, rotasi Promax (Matsunaga, 2011). Hasil menunjukkan bahwa data membentuk 7 faktor dengan varians yang dapat dijelaskan 54,98\%. Scree plot menunjukkan dapat dibentuk 8 faktor. Pengujian dilakukan kembali dengan 8 faktor, tetapi tambahan faktor tersebut tidak menambah variabel laten yang berarti sehingga tetap menggunakan 7 faktor. Gabungan indikator USE dan INT yang menyatu diperlakukan sebagai USE.

Indikator dengan loading factor $<0,7$ adalah PD3, UA1, TS3, TS4, CP2, USE4 dieliminasi sesuai kesepakatan umum analisis faktor. Skor tersebut kemudian disimpan dan diregresikan sesuai hipotesis. Hubungan USE-INT maupun INT-Usage tidak dapat diuji karena tidak terbentuk faktor INT. Regresi skor analisis faktor memenuhi persyaratan asumsi dan hasil regresi (tabel 1 kolom analisis faktor sampel) menunjukkan bahwa hanya hubungan PD-USE yang tidak signifikan pada taraf 0,01 tetapi signifikan pada taraf 0,05. Hasil juga menunjukkan perbedaan dengan regresi penjumlahan skor pada hubungan COM-USE.

\subsection{SEM PLS dan CBSEM}

Pengujian SEMPLS memenuhi persyaratan reliabilitas (Cronbach alpha >0,7). Dari validitas indikator, SEMPLS menunjukkan validitas konstruk tercapai dengan nilai korelasi antar konstruk yang kurang dari akar AVE dan loading factor berada diatas 0,7 (Hair et al., 2014). Sedangkan pada CBSEM metode maximum likelihood, validitas indikator tercapai dengan nilai loading factor $>0,7$ pada masing-masing konstruk. Validitas struktural diuji dengan kriteria Goodness of Fit menunjukkan bahwa model fit dengan nilai chi square tidak signifikan dan berhasil lolos kriteria RMSEA, TLI dan NFI >0,8 (Kline, 2011).

Hasil pengujian (tabel 1 kolom SEMPLS sampel dan CBSEM sampel) menunjukkan perbedaan hasil estimasi kedua metode terjadi pada hubungan COMUSE dimana SEMPLS tidak signifikan sedangkan CBSEM signifikan.

Dari keempat metode yang diujikan, perbedaan yang akan menyebabkan kesalahan tipe 1 terdapat pada hubungan COM-USE atau korelasi antara kenyamanan dan kegunaan. Hipotesis null menyatakan tidak terdapat korelasi antara kenyamanan (COM) dan kegunaan (USE). Pada metode regresi skor analisis faktor dan CBSEM, hipotesis tersebut ditolak. Pada regresi penjumlahan skor dan SEMPLS, hipotesis null tersebut diterima.

\subsection{Penjelasan perbedaan (tahap 2).}

Perbedaan tersebut akan dijelaskan dengan proses eliminasi indikator dan difokuskan pada metode SEM. Pada tabel 2, di bagian SEMPLS kolom I baris COM1, COM2, dan COM3. Pengujian model awal, hubungan COM-USE tidak signifikan dengan korelasi 0.07. Loading factor kurang dari 0,4 terdapat pada indikator COM1 dan COM3. Jikalau eliminasi berdasarkan kriteria loading factor $<0,8,<0,7$, dan $<0,6$ maka COM1 dan COM3 dieliminasi. Setelah dieliminasi, tidak terdapat perubahan pada hubungan COM-USE, yaitu masih tetap tidak signifikan dengan korelasi 0,09-0,10.

Pada CBSEM, tidak diperlukan eliminasi indikator pada COM1, COM2, maupun COM3. Hubungan COM-USE pada pengujian berkorelasi pada kisaran 0,11-0,16 dan pada semua kolom pengujian, hubungan COM-USE signifikan. Pada eliminasi dengan loading factor $<0,8$ (kolom II kanan), model tidak dapat diuji karena hampir semua indikator dieliminasi.

Pengujian dilakukan lebih lanjut, pada kolom X2 (indikator CBSEM dieliminasi menggunakan kriteria yang sama dengan kriteria kolom final SEMPLS) dapat dilihat bahwa hubungan COM-USE di CBSEM menjadi tidak signifikan dan hasil menjadi selaras dengan SEMPLS. Namun, hasil menjadi error dimana loading factor COM1 menjadi > 1 / error indikator menjadi negatif.

Pada kolom X1 (indikator pada SEMPLS dieliminasi menggunakan kriteria kolom final CBSEM), indikator pada COM tidak ada yang dieliminasi, hubungan COM-USE tetap tidak signifikan, tetapi loading factor indikator COM2 menjadi negatif dan loading factor indikator COM1 serta COM3 diatas 0,4. Kemudian, hubungan UAUSE juga menjadi tidak signifikan (sebelumnya signifikan).

Pada pengujian tambahan berupa eliminasi variabel laten, dimana variabel laten pada model dieliminasi satu persatu untuk menguji efeknya, COM-USE berubah menjadi tidak signifikan pada taraf 0.01 pada CBSEM (sesuai dengan estimasi SEMPLS) hanya pada saat konstruk INT dan Usage dieliminasi.

Dari pengujian iteratif tersebut, sumber perbedaan estimasi berasal dari eliminasi indikator / modifikasi model. Metode CBSEM lebih sensitif terhadap eliminasi indikator dibandingkan SEMPLS karena signifikansi dapat berubah ataupun model menjadi tidak lagi dapat diuji. Sedangkan pada SEMPLS, eliminasi indikator tidak terlalu mempengaruhi korelasi maupun signifikansi hubungan yang diuji, khususnya pada variabel laten yang estimasinya berbeda dengan CBSEM (variabel COM).

Dua jalur hasil tersebut dibandingkan dengan data hasil Monte Carlo (tabel 1 kolom MC). Pada hasil $\mathrm{MC}$, empat metode tidak memerlukan eliminasi 
indikator dan hasil akhir mempunyai estimasi yang mayoritas identik.

Dari data MC tersebut hubungan COM-USE signifikan pada semua metode, sesuai dengan estimasi CBSEM dan analisis faktor pada data sampel. Bila merujuk pada hasil Monte Carlo, maka hasil CBSEM merupakan hasil yang terbaik dari pengujian pada data sampel untuk hubungan COMUSE.

\subsection{Diskusi dan implikasi}

Implikasi dari perbedaan hasil pengujian tersebut adalah pemilihan metode memerlukan justifikasi sesuai konteks penelitian yang dilaporkan secara lengkap karena setiap metode memerlukan proses yang akhirnya dapat menghasilkan estimasi yang berbeda walaupun diujikan pada data yang sama.

Pada regresi penjumlahan skor, eliminasi indikator tidak diperlukan sehingga berpotensi bias (Shevlin et al., 1997), analisis faktor dapat mengurangi bias tersebut dengan pengujian indikator, tetapi berpotensi tidak membentuk variabel laten yang sesuai karena eksploratory. Pada SEM/ confirmatory, eliminasi indikator dapat dikontrol tetapi juga akan memengaruhi hasil estimasi akhir.

Eliminasi indikator sebagian ditentukan secara subjektif dengan panduan loading factor. Pada literatur yang ditelusuri, belum berhasil didapatkan pedoman eliminasi yang tepat pada tingkat pasti/ angka tertentu. Riset Shevlin et al. (1997) memberikan panduan loading factor $>0,5$ akan menghasilkan model dengan error yang rendah. Hair memberikan panduan umum dengan loading factor $>$ 0,7 (Hair et al., 2014). Riset Matsunaga menyatakan 0,4 adalah paling rendah, pada umumnya berkisar antara 0,6-0,7 (Matsunaga, 2011). Lowry dan Gaskin menyatakan menggunakan loading factor variabel laten yang tertinggi dibanding loading factor variabel laten lainnya. (Lowry dan Gaskin, 2014). Sarstedt et al. (2016) menyatakan loading factor lebih tinggi akan menghasilkan rata-rata error yang lebih rendah.

Pada tabel 2, SEMPLS baris COM1, COM2, dan COM3. Menurut loading factor maka COM1 dan COM3 dieliminasi. Tetapi dengan berdasar pertanyaan kuesioner atau alat ukur dan pengujian iteratif, diputuskan pertanyaan yang lebih tepat dieliminasi adalah COM2. Kedua proses baik eliminasi COM1 + COM3 maupun hanya eliminasi COM2 menghasilkan estimasi dengan kesimpulan yang sama, yaitu COM-USE tidak signifikan. Tanpa pelaporan yang lengkap, unsur tersebut mungkin tidak diketahui sehingga interpretasi untuk penelitian selanjutnya mungkin tidak menimbang batasan pengujian penelitian sebelumnya (Ropovik, 2015).

Kefasihan teknik SEM berbasis component masih menjadi perdebatan (Rönkkö et al., 2016; Rigdon et al., 2017) sehingga teknik SEM berbasis component lebih disarankan untuk digunakan pada konteks exploratory atau situasi dimana asumsi confirmatory tidak tercapai. Menurut Sarstedt et al. (2016), bias akan sangat tergantung dari model dan data. Jika diasumsikan common factor model/ pengujian teori dengan variabel laten, maka CBSEM lebih tepat. Tetapi pada saat sampel kecil atau pengujian tidak memenuhi syarat CBSEM, SEMPLS akan memberikan hasil yang mendekati CBSEM.

Modifikasi pada model awal SEM (eliminasi indikator) hampir pasti akan dilakukan untuk memenuhi persyaratan metode. Dalam konteks confirmatory dimana hipotesis yang dirumuskan apriori berdasarkan alat ukur yang ditentukan, modifikasi model tersebut mengakibatkan model berubah menjadi approximation atau model tebakan yang mendekati model asli sehingga konteks juga berubah menjadi eksploratory (Tarka, 2018). Oleh karena itu, konteks penelitian perlu menjadi perhatian dalam memilih metode SEM karena akan menentukan apakah metode basis common factor atau basis component yang akan digunakan.

Hasil dari justifikasi metode, pelaporan yang lengkap dan konteks penelitian akan mengurangi potensi kesalahan interpretasi pada penelitian selanjutnya karena asumsi maupun limitasi penelitian akan sudah diketahui dengan jelas.

Pada data penelitian ini, SEMPLS lebih tepat digunakan, karena: Pertama, tidak diketahuinya distribusi populasi/ belum memadainya penelitian sebelumnya sehingga asumsi populasi berdistribusi normal (CBSEM) belum dapat digunakan. Kedua, model mengandung ekstensi yang merupakan konstruk dari teori lain sehingga penelitian mengandung unsur exploratory, maka lebih bersifat menghasilkan artifak untuk menjelaskan penerimaan e-money berdasarkan model yang digunakan. Ketiga, dengan pemilihan SEMPLS, maka penelitian bukan berfokus pada mengkonfirmasi teori, melainkan mengoptimalkan teori pada model (berbasis component) untuk kebutuhan menjelaskan penerimaan e-money berdasarkan ekstensi yang digunakan.

\subsection{Penerimaan e-money di Pontianak.}

Dari hasil pengujian struktural dari SEMPLS, niat menggunakan e-money pada masyarakat kota Pontianak kuat dipengaruhi oleh Kegunaan $\left(\mathrm{R}^{2} 58 \%\right)$. Kegunaan kemudian dipengaruhi oleh Kecepatan, Sosial, Ambiguitas, dan Kompatibilitas dengan $\mathrm{R}^{2}$ $50,3 \%$. Hubungan-hubungan tersebut signifikan pada taraf signifikansi 5\%. Dari semua hipotesis yang diuji di model penelitian, hanya hipotesis 4 dan hipotesis 8 yang ditolak. Dengan demikian, berdasarkan pengujian menggunakan SEMPLS, Hirarki (PD) dan Kenyamanan (COM) tidak memengaruhi niat menggunakan e-money melalui konstruk kegunaan. Sedangkan niat menggunakan signifikan memengaruhi penggunaan riil tetapi hubungan tersebut lemah dengan korelasi hanya bernilai 0,233 dan kemampuan menjelaskan variabilitas kurang dari 
10\%. Hasil tersebut menunjukkan bahwa Niat Menggunakan e-money masyarakat belum diiringi penggunaan riil yang sebanding dan kuat dipengaruhi oleh kecepatan transaksi.

\section{Kesimpulan}

Melalui serangkaian pengujian yang dilakukan, penelitian berhasil menunjukkan perbedaan dari setiap metode dan bagaimana kesalahan type I dapat terjadi. Inkonsistensi estimasi menunjukkan perlunya justifikasi metode maupun konteks penelitian beserta pelaporan lengkap agar potensi kesalahan tipe I dapat diminimalkan.

Terdapat dua kelompok hasil estimasi metode pada data penerimaan e-money yaitu kelompok pertama (regresi penjumlahan skor dan SEMPLS) dengan hasil kenyamanan tidak memengaruhi kegunaan dari e-money, dan kelompok kedua (analisis faktor dan CBSEM) dengan hasil kenyamanan memengaruhi kegunaan dari e-money.

Berdasarkan perbandingan dan justifikasi metode, SEMPLS merupakan metode yang tepat pada kasus data yang digunakan. Hasil pengujian menunjukkan niat menggunakan e-money masyarakat Pontianak tinggi tetapi belum diiringi penggunaan riil yang sebanding. Niat menggunakan tersebut dipengaruhi paling kuat oleh persepsi kegunaan yang dipengaruhi oleh kecepatan, tekanan sosial, ambiguitas, dan kompatibilitas. Sedangkan kecepatan merupakan faktor pengaruh paling kuat dalam mempengaruhi kegunaan dari $e$-money.

Pengujian terbatas karena belum memadainya penelitian sebelumnya tentang e-money pada populasi yang sama. Oleh karena itu, diperlukan banyak penelitian lanjutan pada populasi yang sama dengan alat ukur yang sama sehingga true value maupun distribusi dari populasi dapat ditemukan dan pengujian teori dapat dilakukan lebih akurat. Penelitian lanjutan dapat lebih berfokus pada menjelaskan diskrepansi niat dan penggunaan riil.

Dari metode yang diujikan, keterbatasan terdapat pada regresi hanya dari OLS, analisis faktor hanya dari principal axis, CBSEM hanya dari maximum likelihood, dan SEMPLS hanya pada indikator reflektif. Pada penelitian lanjutan perbandingan dapat dikembangkan ke metode yang sama tetapi dengan teknik perhitungan yang berbeda.

\section{Ucapan Terima Kasih}

Kepada DIKTI atas pendanaan skema pdp. Editor dan Reviewer atas saran konstruktif.

\section{Daftar Pustaka}

Baptista, G., Oliveira, T., 2015. Understanding mobile banking: The unified theory of acceptance and use of technology combined with cultural moderators. Computers in Human Behavior 50, 418-430.

Blessing, L. T. M., Chakrabarti, A., 2009. DRM, a design research methodology. New York, Springer.

Bollen, K. A., 1989. Structural Equations with Latent Variables. New York, John Wiley \& Sons.

Carsey, T.M., Harden, J.J., 2014. Monte Carlo Simulation and Resampling Methods for Social Science. New York. Sage.

Cash, P., 2020. Where next for design research? Understanding research impact and theory building. Design Studies 68, 113-141.

Davis, F.D., Bagozzi, R.P., Warshaw, P.R., 1983. User acceptance of computer technology: a comparison of two theoretical models. Management Science, 35(8), 982-1003.

Dwivedi, Y.K., Rana, N.P., Jeyaraj, A., Clement, M., Williams, M. D., 2019. Re-examining the Unified Theory of Acceptance and Use of Technology (UTAUT): towards a revised theoretical model. Information Systems Frontiers, 21(3), 719-734.

Elsevier, 2020. ScienceDirect Search Keyword Technology Acceptance Model. Website: https://www.sciencedirect.com/search?qs=technol ogy acceptance model, diakses 2 Nov 2020.

Gorsuch, R.L., 1983. Factor Analysis. New York. Lawrence Erlbaum Associates.

Hair, J.F., 2010. Multivariate data analysis. New York. Prentice Hall.

Hair, J.F., Hult, G.T.M., Ringle, C.M., Sarstedt, M., 2014. A Primer on Partial Least Squares Structural Equation Modeling (PLS-SEM). New York. Sage Publishing.

Ishak, 2019. Wali Kota Pontianak Edi Kamtono Ingin Cegah Kegaduhan, Isi BBM di SPBU Pontianak Tak Wajib Cashless. Website: https://pontianak.tribunnews.com/2019/09/05/wal i-kota-pontianak-edi-kamtono-ingin-cegah-kega duhan-isi-bbm-di-spbu-pontianak-tak-wajib-cash less?page=all, diakses 1 Nov 2020.

Kline, R.B., 2011. Principles and Practice of Structural Equation Modeling. In Clinical orthopaedics and related research. New York. The Guilford Press.

Lok, C.K., 2015. Adoption of Smart Card-Based EPayment System for Retailing in Hong Kong Using an Extended Technology Acceptance Model. E-Services Adoption: Processes by Firms in Developing Nations 23B, 255-466.

Lowry, P.B., Gaskin, J., 2014. Partial least squares (PLS) structural equation modeling (SEM) for building and testing behavioral causal theory: When to choose it and how to use it. IEEE Transactions on Professional Communication, 57(2), 123-146.

Matsunaga, M., 2011. How to Factor-Analyze Your Data Right: Do's, Don't s, and How-To's. 
International Journal of Psychological Research 3(1), 97-110.

Mortimer, G., Neale, L., Hasan, S.F.E., Dunphy, B., 2015. Investigating the factors influencing the adoption of m-banking: a cross cultural study. International Journal of Bank Marketing 33(4), 545-570.

Rigdon, E.E., Sarstedt, M., Ringle, C.M., 2017. On Comparing Results from CB-SEM and PLSSEM: Five Perspectives and Five Recommendations. Marketing ZFP 39(3), 4-16.

RISTEK DIKTI., 2020. Garba Rujukan Digital (GARUDA) Search Keyword Technology Acceptance Model. Website: http://garuda.riste kbrin.go.id /documents?q=technology+accep tance+model+,diakses 1 Nov 2020.

Rönkkö, M., McIntosh, C.N., Antonakis, J., Edwards, J.R., 2016. Partial least squares path modeling: Time for some serious second thoughts. Journal of Operations Management, 47, 9-27.

Ropovik, I., 2015. A cautionary note on testing latent variable models. Frontiers in Psychology 6, 1-8.

Sarstedt, M., Hair, J. F., Ringle, C. M., Thiele, K. O., Gudergan, S.P. 2016. Estimation issues with PLS and CBSEM: Where the bias lies! Journal of Business Research, 69(10), 3998-4010.
Shevlin, M., Miles, J.N.V., Bunting, B.P., 1997. Summated rating scales: A Monte Carlo investigation of the effects of reliability and collinearity in regression models. Personality and Individual Differences, 23(4), 665-676.

Syahroni., 2018. Pelayanan E-money di SPBU kota Pontianak Memperlambat Transaksi. Website: http://pontianak.tribunnews.com/2018/01/01/pela yanan-e-money-di-spbu-kota-pontianak-memp erlambat-transaksi, diakses 1 Nov 2020.

Tabachnick, B.G., Fidell, L.S., 2013. Using Multivariate Statistics. Boston, Prentice Hall.

Tarka, P., 2018. An overview of structural equation modeling: its beginnings, historical development, usefulness and controversies in the social sciences. Quality and Quantity 52(1), 313-354.

Tóth-Király, I., Bõthe, B., Rigó, A., Orosz, G., 2017. An illustration of the Exploratory structural equation modeling (ESEM) framework on the passion scale. Frontiers in Psychology 8, 1-15.

Velicer, W.F., Jackson, D.N., 1990. Component Analysis versus Common Factor Analysis: Some Issues in Selecting an Appropriate Procedure. Multivariate Behavioral Research 25(1), 1-28.

Venkatesh, V., Davis, F.D., 2000. Theoretical extension of the Technology Acceptance Model: Four longitudinal field studies. Management Science, 46(2), 186-204. 